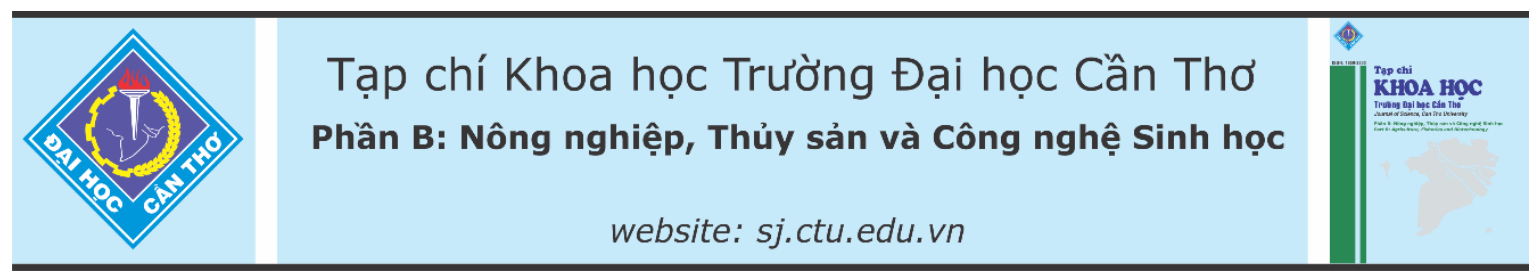

DOI:10.22144/ctu.jvn.2021.127

\title{
TỐI ƯU CÁC ĐIỀU KIỆN SINH ENZYME PROTEASE NGOẠI BÀO CỦA VI KHUẦN Streptomyces DH3.4
}

\author{
Phạm Thị Tuyết Ngân*, Vũ Hùng Hải, Huỳnh Trường Giang và Vũ Ngọc Út
}

Bộ môn Thủy sinh họ úng dụng, Khoa Thủy sản, Truờng Đại học Cần Tho

*Người chịu trách nhiệm về bài viết: Phạm ThịTuyết Ngân (email: pttngan@ctu.edu.vn)

\section{Thông tin chung:}

Ngày nhận bài: 07/03/2021

Ngày nhận bài sưa: 26/06/2021

Ngày duyệt đăng: 20/08/2021

\section{Title:}

Optimal protease enzyme production activity of

Streptomyces DH3.4

\section{Tù khóa:}

Enzyme protease, $\mathrm{NaCl}$, nguồn carbon, nguồn nitrogen, $\mathrm{pH}$,

Streptomyces

\section{Keywords:}

Carbon source, $\mathrm{NaCl}$, nitrogen source, $\mathrm{pH}$, protease enzyme, Streptomyces

\section{ABSTRACT}

This study was conducted under in vitro conditions to assess the effect of culture conditions on the protease production of Streptomyces DH3.4. Experiments were conducted in various $p H$ levels $(4,5,6,7,8$ and 9) and different concentrations of $\mathrm{NaCl}(0 ; 0.5 ; 1 ; 1,5 ; 2 ; 2.5 ; 3$ and 3.5\%). The incubation time in the experiment was observed at intervals of 24, 48, 72, 96, 120, 144 and 168 hours. The sources of carbon used in the experiment were glycerol, D-glucose, sucrose, D-maltose, D-xylose, soluble starch with a concentration of $1 \%$. Organic nitrogen sources were chosen such as casein, malt extract, peptone, tryptone, soybean meal, and yeast extract with a concentration of $0.5 \%$. The sources of inorganic nitrogen including

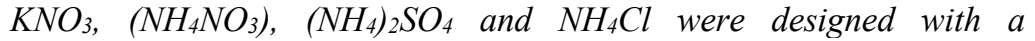
concentration of $0.1 \%$. Each experiment was run in triplicates. The results showed that the maximum protease production from Streptomyces strain DH3.4 was found under culture conditions adjusted to $\mathrm{pH} 7.0,1.5 \%$ $\mathrm{NaCl}$ and 144 hours of incubation. Starch performed the sole source of carbon, whereas malt extract and $\left(\mathrm{NH}_{4}\right)_{2} \mathrm{SO}_{4}$ were the superior organic and inorganic substrates, respectively.

\section{TÓM TẮT}

Nghiên cúu được thưc hiện trong điều kiện in vitro nhằm đánh giá sự ảnh huởng của các yếu tố môi truờng lên hoạt tính enzyme protease của vi khuẩn Streptomyces DH3.4. Thi nghiệm thực hiện ở các môi truờng $p H$ khác nhau 4; 5; 6; 7; 8 và 9, nồng độ $\mathrm{NaCl} 0 ; 0,5 ; 1 ; 1,5 ; 2 ; 2,5 ; 3$ và $3,5 \%$. Thời gian quan sát trong thí nghiệm là $24,48,72,96,120,144$ và 168 giờ. Nguồn carbohydrate sủ dụng trong thi nghiệm là glycerol, Dglucose, sucrose, D-maltose, D-xylose, soluble starch với nồng độ $1 \%$. Nguồn nitrogen hũu cơ sử dụng là casein, malt extract, peptone, tryptone, bã đậu nành, yeast extract với nồng độ $0,5 \%$. Nguồn nitơ vô co bao bồm $\mathrm{KNO}_{3}, \mathrm{NH}_{4} \mathrm{NO}_{3},\left(\mathrm{NH}_{4}\right)_{2} \mathrm{SO}_{4}$ và $\mathrm{NH}_{4} \mathrm{Cl}$ được bố trí với nồng độ $0,1 \%$. Thi nghiệm đươ bố trí với 3 lần lặp lại. Kết quả cho thấy khả năng sinh hoạt tính protease cao nhất của chủng Streptomyces DH3.4 được ghi nhận ở điều kiện nuôi cấy pH 7,0; 1,5\% NaCl và thời gian nuôi cấy là 144 giò̀. Tinh bột là nguồn carbon tốt nhất, trong khi malt extract và $\left(\mathrm{NH}_{4}\right)_{2} \mathrm{SO}_{4}$ lần lượt là các co chất đạm hũu co và vô co tối uu. 


\section{GIỚI THIỆ}

Protease là một trong những enzyme có nhiều ứng dụng rộng rãi phục vụ cho đời sống, trong các ngành công nghiệp thực phẩm, dệt may, dược phẩm. Protease có thể thu nhận từ các nguồn: thực vật, động vật và vi sinh vật. Trong đó, vi sinh vật là nguồn cho protease phong phú nhất. Một số loài vi sinh vật có khả năng tổng hợp protease như: Streptomyces griseus (Nomoto et al., 1960), Bacillus subtilis (Đỗ Thị Bích Thủy, 2012), B. cereus, Streptomyces rimosus và Aspergillus oryzae... Trong đó, enzyme protease được sản xuất với sản lượng lớn nhất chủ yếu từ vi khuẩn Bacillus mặc dù có nhiều nguồn vi khuẩn để sản xuất protease nhưng chỉ có một số ít được nghiên cứu ứng dụng trong sản xuất thương mại. Về phương diện tổng hợp protease, Streptomyces được nghiên cứu ít hơn vi khuẩn Bacillus và nấm mốc. Tuy nhiên, người ta cũng đã tìm ra được một số loài có khả năng tổng hợp protease cao như: Streptomyces grieus, $S$. fradiae, $S$. terimosus,... Các chế phẩm protease từ vi khuẩn được biết nhiều là pronase (Nhật) được chiết tách từ Streptomyces grieus, enzyme này có tính đặc hiệu rộng, có khả năng thủy phân hơn $90 \%$ các liên kết peptide thành các amino acid. Vi khuẩn Streptomyces có khả năng tiết ra enzyme protease ngoại bào và có thể được nuôi cấy trong điều kiện nhiệt độ, $\mathrm{pH}$ thích hợp để tạo ra các sản phẩm với các đặc tính ổn định trong các điều kiện môi trường khác nhau. Trên cơ sở đó các nghiên cứu được tiến hành để thu được nguồn protase có hàm lượng hoạt tính cao cần tối ưu từ nguồn phân lập, phương pháp thực hiện, điều kiện nuôi cấy, đặc biệt là thành phần và cơ chất cảm ứng trong môi trường nuôi. Do đó thí nghiệm được tiến hành nhằm tối ưu các điều kiện nuôi cấy trong in vitro lên khả năng sinh enzyme protease của chủng vi khuẩn Streptomyces DH 3.4.

\section{PHƯƠNG PHÁP NGHIÊN CÚU}

\subsection{Phương pháp nghiên cứu}

\subsection{1. Đối tuợng thí nghiệm}

Chủng vi khuẩn Streptomyces DH3.4 được phân lập từ bùn ao nuôi tôm thẻ chân trắng Litopenaeus vannamei ở tỉnh Trà Vinh với hoạt tính kháng khuẩn Vibrio parahaemolyticus và hoạt tính enzyme cao (Phạm Văn Nhuần, 2020) và bảo quản tại phòng thí nghiệm Vi sinh vật hữu ích, Bộ môn Thủy sinh học ứng dụng, Khoa Thủy sản, Trường Đại học Cần Tho.

\subsubsection{Phuơng pháp chuẩn bị bào tử vi khuẩn}

Chủng vi khuẩn Streptomyces DH3.4 được phục hồi và nuôi trên môi trường starch casein agar
(SCA) ở $30^{\circ} \mathrm{C}$ trong 5 ngày đến khi bào tử vi khuẩn xuất hiện. Hút $3 \mathrm{~mL}$ nước muối sinh lý tiệt trùng $(0,9 \% \mathrm{NaCl})$ và 1 giọt dung dịch $0,1 \%$ Tween 80 (chất hoạt động bề mặt) vào đĩa SCA chứa bào tử vi khuẩn Streptomyces (El-Shatoury et al., 2020), sau đó dùng que cấy khử trùng tách nhẹ nhàng các bào tử trên khuẩn lạc vào dung dịch trên và hút chuyển vào ống nghiệm tiệt trùng. Huyền phù bào tử Streptomyces được điều chỉnh giá trị $\mathrm{OD}=0,2$ ở bước sóng $540 \mathrm{~nm}$ (Sengupta \& Paul, 1992) bằng nước muối sinh lý tiệt trùng và mật độ vi khuẩn Streptomyces $\mathrm{sp}$. được xác định bằng phương pháp cấy trải (APHA, 2017) trên môi trường SCA ở $30^{\circ} \mathrm{C}$ trong 5 ngày để phục vụ cho các nghiên cứu tiếp theo.

\subsubsection{Phuơng pháp tối uu các điều kiện lý hóa trong quá trình lên men \\ a. Tối ưu pH của môi trường}

Thí nghiệm được tiến hành trong điều kiện in vitro như sau: dùng micro pipette chuyển $100 \mu \mathrm{L}$ huyền phù bào tử $\left(\mathrm{OD}_{540}=0,2\right)$ vào ống nghiệm chứa $9,9 \mathrm{~mL}$ môi trường starch casein broth $(\mathrm{SCB})$ đã được điều chỉnh độ $\mathrm{pH}$ bằng $\mathrm{NaOH}$ và $\mathrm{HCl}$ để đạt các giá trị lần lượt là $4,5,6,7,8$ và 9 . Ống nghiệm chứa môi trường $\mathrm{SCB}$ và $100 \mu \mathrm{L}$ nước muối sinh lý $(0,9 \% \mathrm{NaCl})$ được chuẩn bị để làm đối chứng và mỗi nồng độ $\mathrm{pH}$ được bố trí với 3 lần lặp lại. Sau 5 ngày nuôi cấy ở $30^{\circ} \mathrm{C}$ trên máy lắc (tốc độ 150 vòng/phút), mẫu được tiến hành ly tâm thu phần dịch nổi (cell free supernatant, CFS) để đánh giá hoạt tính enzyme protease và phần sinh khối tế bào (cell biomass) được xác định trọng lượng khô (dry cell weight).

\section{b. Anh hưởng nồng độ $\mathrm{NaCl}$}

Thí nghiệm nhằm đánh giá ảnh hưởng của các nồng độ $\mathrm{NaCl}$ lên hoạt tính enzyme của chủng vi khuẩn. Cụ thể như sau: ống nghiệm chứa $9,9 \mathrm{~mL}$ môi trường $\mathrm{SCB}$ được điều chỉnh nồng độ $\mathrm{NaCl}$ (ở các nồng độ $0 ; 0,5 ; 1 ; 1,5 ; 2 ; 2,5 ; 3$ và $3,5 \%$ ) và 100 $\mu \mathrm{L}$ huyền phù bào tử $\left(\mathrm{OD}_{540}=0,2\right)$ được ủ ở $30^{\circ} \mathrm{C}$ trên máy lắc (tốc độ 150 vòng/phút) trong 5 ngày. Dùng $100 \mu \mathrm{L}$ nước muối sinh lý $0,9 \% \mathrm{NaCl}$ thay thế huyền phù bào tử để làm nghiệm thức đối chứng. Phần dịch CFS và sinh khối tế bào được thu bằng phương pháp ly tâm để xác định hoạt tính enzyme và trọng lượng khô. Thí nghiệm được thực hiện với 3 lần lặp lại.

\section{c. Anh hương của các nguồn carbohydrate}

Nguồn carbohydrate $(\mathrm{C})$ sử dụng trong thí nghiệm bao gồm glycerol, d-glucose, sucrose, dmaltose, $\mathrm{d}$-xylose, soluble starch được bổ sung vào 
môi trường $\mathrm{SCB}$ với nồng độ $1 \%$ (Al-Dhabi et al., $2020 \mathrm{~b}$ ) và $100 \mu \mathrm{L}$ huyền phù bào tử vào ống nghiệm đã bổ sung các nguồn $\mathrm{C}$ thay thế. Thí nghiệm được lặp lại với 3 lần. Hoạt tính enzyme và trọng lượng khô của tế bào được xác định sau 5 ngày nuôi cấy ở $30^{\circ} \mathrm{C}$ trên máy lắc (tốc độ 150 vòng/phút).

\section{d. Anh hưởng của các nguồn nitrogen}

Thí nghiệm được thực hiện tương tự như phương pháp mô tả ở trên với 2 nguồn nitrogen $(\mathrm{N})$ hữu cơ và vô cơ. Nguồn $\mathrm{N}$ hữu cơ: gồm casein, malt extract, peptone, tryptone, bã đậu nành, yeast extract vào môi trường $\mathrm{SCB}$ được chuẩn bị với nồng độ $0,5 \%$ (Haritha et al., 2012). Nguồn $\mathrm{N}$ vô cơ: môi trường SCB được bồ sung lần lượt các nguồn $\mathrm{KNO}_{3}$, $\left(\mathrm{NH}_{4} \mathrm{NO}_{3}\right),\left(\mathrm{NH}_{4}\right)_{2} \mathrm{SO}_{4}, \mathrm{NH}_{4} \mathrm{Cl}$ với nồng độ $0,1 \%$ (Haritha et al., 2012). Ông nghiệm chứa môi trường SCB đã điều chỉnh các nguồn $\mathrm{N}$ khác nhau được bổ sung $100 \mu \mathrm{L}$ huyền phù bào tử và đánh giá hoạt tính protease sau 5 ngày nuôi cấy ở $30^{\circ} \mathrm{C}$ trên máy lắc (tốc độ 150 vòng/phút). Các nghiệm thức trong thí nghiệm được tiến hành trong điều kiện in vitro với 3 lần lặp lại.

\section{e. Anh hưởng của thời gian nuôi cấy lên hoạt tinh enzyme protease}

Hoạt tính enzyme của chủng vi khuẩn Streptomyces DH3.4 được đánh giá ở các mốc thời gian nuôi cấy khác nhau. Ống nghiệm chứa $9,9 \mathrm{~mL}$ môi trường $\mathrm{SCB}$ được điều chỉnh nồng độ $\mathrm{NaCl}$ và $\mathrm{pH}$ ở giá trị tốt nhất dựa vào kết quả đạt được ở các thí nghiệm trên, sau đó hút $100 \mu \mathrm{L}$ huyền phù bào tử $\left(\mathrm{OD}_{540}=0,2\right)$ vào các ống nghiệm chứa môi trường $\mathrm{SCB}$ và $100 \mu \mathrm{L}$ nước muối sinh lý $0,9 \% \mathrm{NaCl}$ được sử dụng để làm nghiệm thức đối chứng. Hoạt tính enzyme và trọng lượng khô của tế bào được xác định sau $24,48,72,96,120,144$ và 168 giờ nuôi (Akhtar et al., 2013) ở $30^{\circ} \mathrm{C}$ trên máy lắc (tốc độ 150 vòng/phút). Thí nghiệm được thực hiện với 3 lần lặp lại.

\subsection{4. Đánh giá hoạt tính enzyme protease ngoại bào}

Ly trích enzyme: Sau 5 ngày nuôi cấy, ly tâm huyền phù ở tốc độ 8.000 vòng/phút trong 10 phút ở $4^{\circ} \mathrm{C}$ để loại bỏ tế bào vi khuẩn và thu phần dịch nổi phía trên để xác định hoạt tính enzyme protease (Fernandes et al. 2019) và trọng lượng khô của tế bào.

Hoạt tính protease được xác định dựa theo phương pháp Lowry được mô tả bởi Huynh et al.
(2018) như sau: $100 \mu \mathrm{L}$ dịch enzyme ủ với $100 \mu \mathrm{L}$ dung dịch $1 \%$ casein (pha trong dung dịch đệm Tris$\mathrm{HCl} ; \mathrm{pH} 9,0$ ) trong 10 phút ở $37^{\circ} \mathrm{C}$ và thêm $500 \mu \mathrm{L}$ dung dịch $5 \%$ trichloroacetic acid thêm vào để ngừng phản ứng. Sau 30 phút, hỗn hợp trên được ly tâm ở tốc độ $8000 \mathrm{rpm}$ trong 5 phút ở $4^{\circ} \mathrm{C}$ và thu phần dịch nổi bên trên để xác định hoạt tính enzyme theo phương pháp Lowry et al. (1951). Mỗi đơn vị (Unit) hoạt tính enzyme protease tương đương với lượng enzyme cần thiết để phân giải casein và phóng thích $1 \mu \mathrm{g}$ tyrosine $/ \mathrm{mL} /$ phút.

Phương pháp xác định trọng lượng khô: Sinh khối tế bào vi khuẩn được xác định bằng phương pháp trọng lượng theo mô tả trước đây của van Veen and Paul (1979), cụ thể là $10 \mathrm{~mL}$ huyền phù vi khuẩn Streptomyces DH3.4 ở độ pha loãng với các $10^{-1}, 10^{-}$ ${ }^{2}$ được lọc qua giấy lọc Whatman tiệt trùng với đường kính lỗ lọc $0,22 \mu \mathrm{m}$. Mẫu giấy lọc được xử lý nhiệt ở $110^{\circ} \mathrm{C}$ đến khi trọng lượng không đổi. Cân và xác định trọng lượng mẫu để tính trọng lượng sinh khối tế bào $(\mathrm{mg} / \mathrm{mL})$.

\subsubsection{Phương pháp xủ lý số liệu}

Số liệu thu thập được tính toán giá trị trung bình, độ lệch chuẩn bằng phần mềm Microsoft Excel 2013 và so sánh sự khác biệt giữa các nghiệm thức theo phương pháp phân tích ANOVA một nhân tố với phép thử Duncan bằng phần mềm thống kê SPSS 22.0 ở mức ý nghĩa 95\% $(\mathrm{p}<0,05)$.

\section{KẾT QUẢ VÀ THẢO LUẬN}

\section{1. Ảnh hưởng của pH}

Trong thí nghiệm đánh giá khả năng sinh hoạt tính enzyme protease từ Streptomyces $\mathrm{DH} 3.4$ bằng phương pháp nuôi cấy chìm, $\mathrm{pH}$ môi trường có ảnh hưởng đáng kể đến hàm lượng hoạt tính protease thu được do vi khuẩn sinh ra trong quá trình nuôi cấy. Tùy vào giá trị $\mathrm{pH}$ khác nhau sẽ thu được hoạt tính protease ở các giá trị khác nhau. Kết quả (Hình 1) cho thấy hoạt tính enzyme protease cao ở $\mathrm{pH} 6,7$ và 8. Tuy nhiên ở $\mathrm{pH} 7(46,2 \pm 2,7 \mathrm{U} / \mathrm{mg})$ hoạt tính ezyme protease đạt giá trị cao nhất và đạt giá trị thấp nhất ở $\mathrm{pH} 4(28,8 \pm 2,6 \mathrm{U} / \mathrm{mg})$ và khác biệt có ý nghĩa thống kê. Kết quả nghiên cứu này tương đồng với nghiên cứu của Akhtar et al. (2013), sản phẩm enzyme protease của Streptomyces tối ưu ở pH 7. Và trái ngược với một nghiên cứu khác của Al-Dhabi et al. (2020a) và Jayasree et al. (2009) nghiên cứu trên Streptomyces sp. cho thấy ở $\mathrm{pH} 9$ lại sinh protease mạnh nhất. 


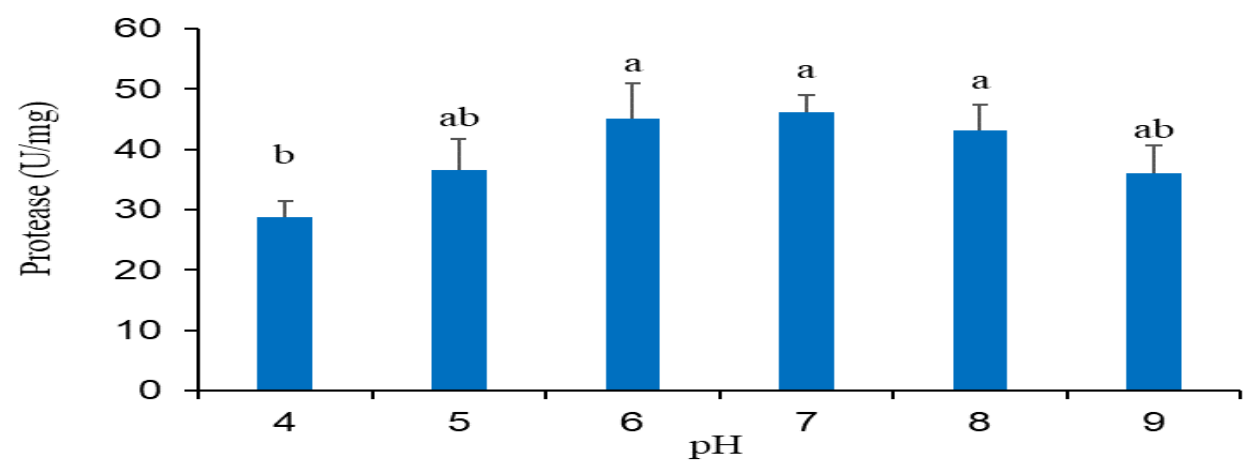

Hình 1. Ảnh hưởng của pH môi trường đến hoạt tính protease

Các ký tụ khác nhau trên mỗi cột cho thấy sụ khác biệt giũa các giá trị pH trong thí nghiệm $(p<0,05)$.

\section{2. Ảnh hưởng của $\mathrm{NaCl}$}

Nồng độ muối $\mathrm{NaCl}$ có ảnh hưởng lớn đến khả năng sinh trưởng và sinh enzyme protease ngoại bào. Kết quả vi khuẩn Streptomyces DH3.4 được nuôi cấy trong môi trường SCB ở nồng độ $0 ; 0,5 ; 1$; 1,$5 ; 2 ; 2,5 ; 3$ và $3,5 \%$ (Hình 2 ) cho thấy khả năng thu nhận hoạt tính enzyme protease ngoại bào đạt hiệu quả tốt trong khoảng nồng độ muối $1-2 \%$ và đạt cao nhất nồng độ muối $1,5 \%(37 \pm 4,3 \mathrm{U} / \mathrm{mg})$ và đạt giá trị thấp nhất 3,5\% $(15,9 \pm 2,4 \mathrm{U} / \mathrm{mg})$. Tuy nhiên, nồng độ $\mathrm{NaCl}$ thấp hơn $1 \%$ và cao hơn $2 \%$, chúng vẫn có khả năng sinh hoạt tính enzyme protease ngoại bào nhưng hàm lượng hoạt tính enzyme protease thấp hơn $\mathrm{NaCl}$. Theo kết quả nghiên cứu của Jayasree et al. (2009) trên loài Streptomyces pulvereceus, hoạt tính enzyme protease cao nhất ở nồng độ $1 \% \mathrm{NaCl}$. Trong nghiên cứu hiện tại, chủng Streptomyces DH3.4 đạt hoạt tính cao nhất ở nồng độ $1,5 \% \mathrm{NaCl}$ do chủng vi khuẩn được phân lập từ vùng nuôi tôm nước lợ.

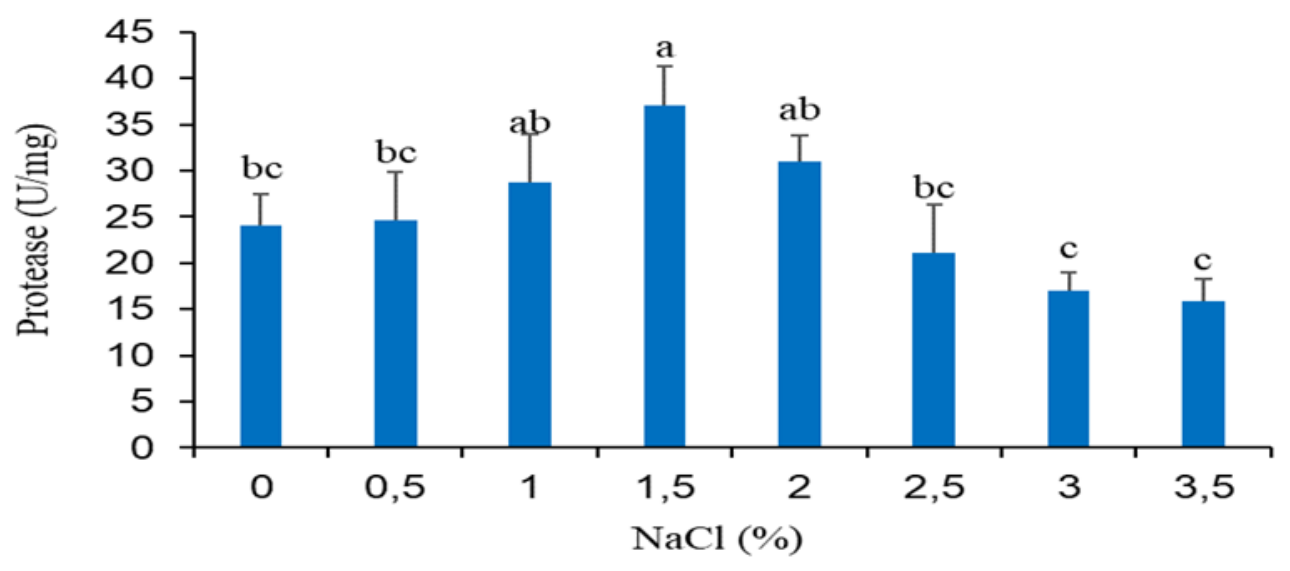

Hình 2. Ảnh hưởng nồng độ $\mathrm{NaCl}$ lên hoạt tính enzyme protease

Các ký tụ khác nhau trên mỗi cột cho thấy sự khác biệt giữa các nồng độ $\mathrm{NaCl}$ trong thí nghiệm $(p<0,05)$.

\section{3. Ảnh hưởng nguồn carbohydrate}

Trong nghiên cứu này, khả năng sinh enzyme protease từ vi khuẩn Streptomyces DH3.4 cho thấy hoạt tính protease thu được hiệu quả nhất với glucose là $49,4 \pm 4,1 \mathrm{U} / \mathrm{mg}$ và soluble starch $52,1 \pm$ $4,5 \mathrm{U} / \mathrm{mg}$ trong đó soluble starch là cao nhất và nguồn carbon có hoạt tính enzyme protease thu được thấp nhất là sucrose $(32,7 \pm 6,9 \mathrm{U} / \mathrm{mg}$ ) (Hình 3).
Theo nghiên cứu của Al-Dhabi et al. (2020a), chủng Streptomyces sp. Al-Dhabi-82 sinh hoạt tính protease cao nhất với 1,5\% maltose so với các nguồn carbon khác như glucose, lactose, fructose, tinh bột và trehalose. Tuy nhiên, kết quả của thí nghiệm tương đồng với nghiên cứu của Nayera et al. (2014) rằng tinh bột là nguồn carbon để tối ưu hoạt tính protease tiết ra bởi nhóm vi khuẩn Streptomyces sp. 


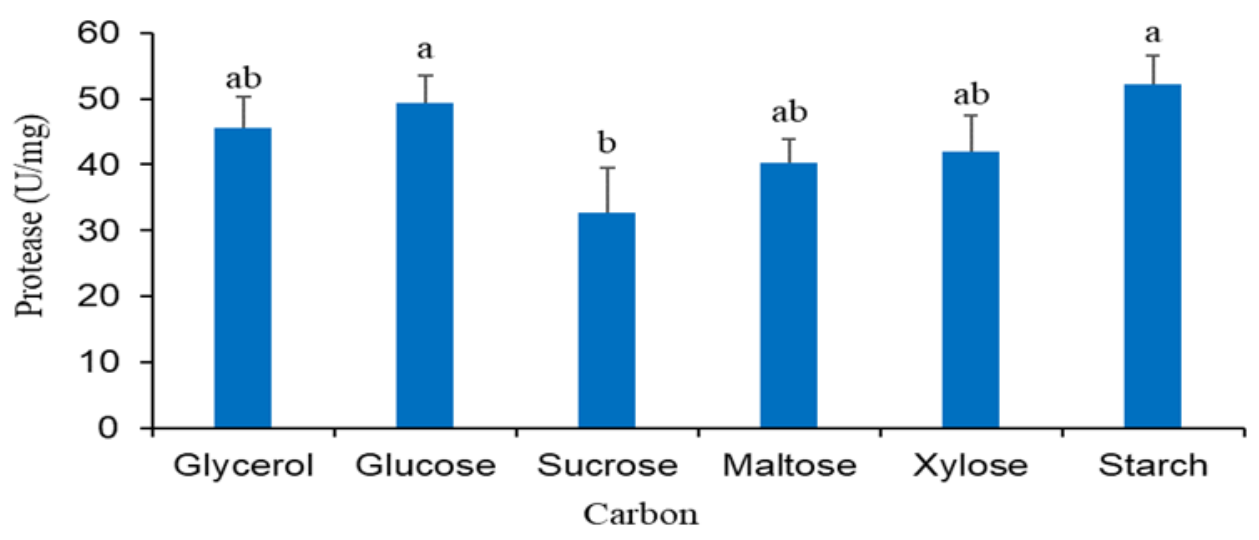

Hình 3. Ảnh hưởng nguồn Carbon lên hoạt tính enzyme protease

Các ký tụ khác nhau trên mỗi cột cho thấy sự khác biệt giữa các nồng độ Carbohydrate trong thí nghiệm $(p<0,05)$.

\section{4. Ảnh hưởng nguồn nitrogen}

Kết quả cho thấy nguồn $\mathrm{N}$ hữu cơ đươc thực hiện trong thí nghiệm bằng cách thay thế casein trong môi trường $\mathrm{SCB}$ ban đầu bằng các nguồn $\mathrm{N}$ hữu cơ khác như casein, malt extract, peptone, tryptone, bã đậu nành, yeast extract vào môi trường $\mathrm{SCB}$ được chuẩn bị với nồng độ $0,5 \%$. Kết quả cho thấy nguồn nitrogen hữu cơ cho enzyme với hoạt tính enzyme protease cao là malt extract và peptone. Tuy nhiên malt extract là nguồn nitrogen hữu cơ cho hoạt tính enzyme protease cao nhất $(64,2 \pm 2,6 \mathrm{U} / \mathrm{mg})$ cao hơn casein $(47,1 \pm 7 \mathrm{U} / \mathrm{mg})$, tryptone $(47,7 \pm 5,5 \mathrm{U} / \mathrm{mg})$, bã đậu nành $(47,7 \pm 5,6 \mathrm{U} / \mathrm{mg})$, yeast extract $(39,1$ $\pm 7,2 \mathrm{U} / \mathrm{mg}$ ) (Hình 4). Kết quả nghiên cứu của Haritha et al. (2012) và kết quả của nghiên cứu này trái ngược với nhau, kết quả của Haritha cho thấy bã đậu nành là nguồn nitrogen hữu cơ sản sinh enzyme protease hoạt tính cao nhất và trong thí nghiệm này kết quả malt extract là nguồn $\mathrm{N}$ hữu cơ sinh enzyme protease cao nhất.

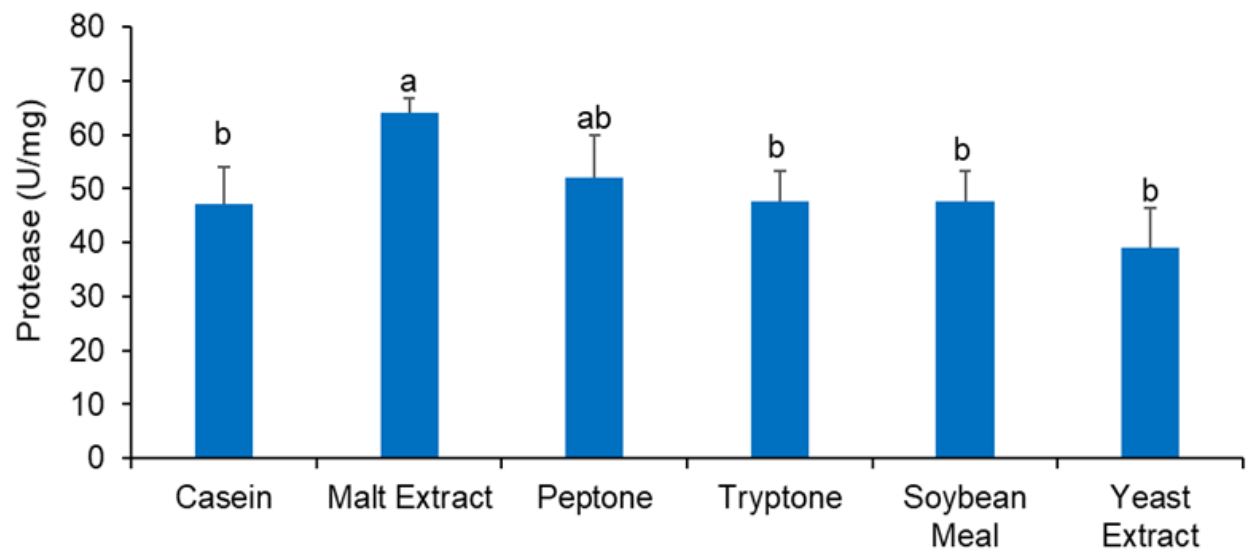

Nitơ hữu cơ

\section{Hình 4. Ảnh hưởng nguồn $\mathrm{N}$ hữu cơ lên hoạt tính enzyme protease}

Các ký tự khác nhau trên mỗi cột cho thấy sư khác biệt giũa các nguồn $N$ hũu co trong thí nghiệm $(p<0,05)$.

Nguồn $\mathrm{N}$ vô cơ môi trường $\mathrm{SCB}$ được bổ sung lần lượt là $\mathrm{KNO}_{3},\left(\mathrm{NH}_{4} \mathrm{NO}_{3}\right),\left(\mathrm{NH}_{4}\right)_{2} \mathrm{SO}_{4}$ và $\mathrm{NH}_{4} \mathrm{Cl}$ với nồng độ $0,1 \%$. Kết quả cho thấy khi sử dụng nitrogen vô cơ hoạt tính enzyme protease thu được cao nhất lần lượt là $\left(\mathrm{NH}_{4}\right) \mathrm{SO}_{4}(66,2 \pm 9 \mathrm{U} / \mathrm{mg})$ và $\mathrm{KNO}_{3}(58,3 \pm 3,5 \mathrm{U} / \mathrm{mg})$, đạt hiệu quả hơn $\mathrm{NH}_{4} \mathrm{NO}_{3}$
$(38 \pm 3,6 \mathrm{U} / \mathrm{mg})$ và $\mathrm{NH}_{4} \mathrm{Cl}(31,1 \pm 4,2 \mathrm{U} / \mathrm{mg})$ (Hình 5). Theo Haritha et al. (2012), kết quả thí nghiệm của ông và kết quả của thí nghiệm này tương đồng với nhau đều cho thấy $\left(\mathrm{NH}_{4}\right)_{2} \mathrm{SO}_{4}$ là nguồn nitơ vô cơ sản sinh enzyme protease hoạt tính cao nhất trong khảo sát. 


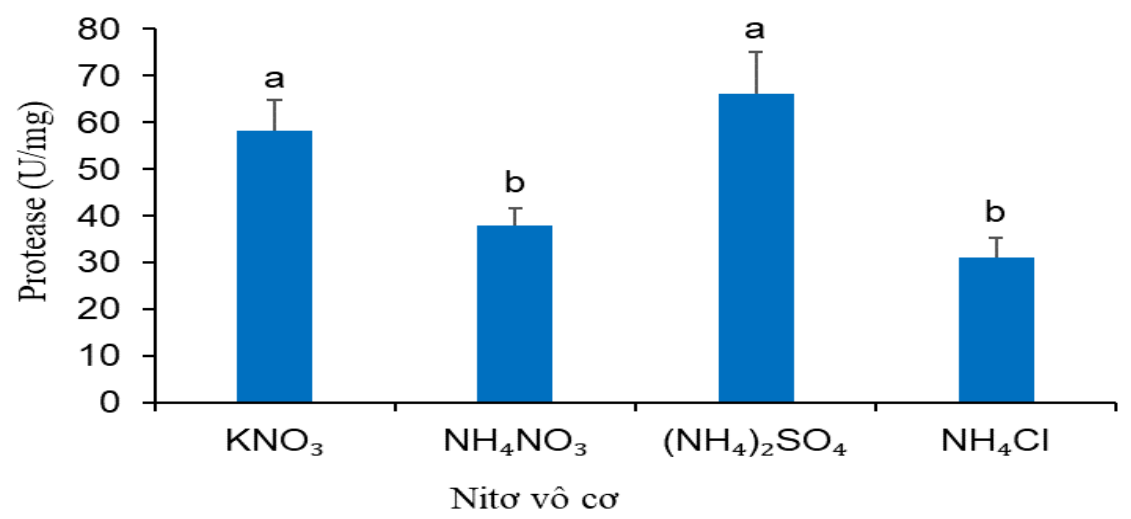

Hình 5. Ảnh hưởng nguồn $\mathrm{N}$ vô cơ lên hoạt tính enzyme protease

Các ký tụ khác nhau trên mỗi cột cho thấy sụ khác biệt giữa các nguồn $N$ vô cơ trong thí nghiệm $(p<0,05)$.

Trong quá trình nuôi cấy, sự sinh tổng hợp protease chịu ảnh hưởng lớn bởi thành phần dinh dưỡng và chất cảm ứng bổ sung vào môi trường nuôi cấy. Tùy vào đặc tính của từng loài vi khuẩn sử dụng trong quá trình thí nghiệm và điều kiện nuôi biểu hiện mà nhu cầu về các thành phần dinh dưỡng sẽ khác nhau trong quá trình sinh tổng hợp enzyme protease. Và quá trình sinh tổng hợp enzyme protease từ chủng $\mathrm{DH} 3.4$ trong thí nghiệm này cho thấy nguồn $\mathrm{N}$ được sử dụng tốt là malt extractvà $\left(\mathrm{NH}_{4}\right)_{2} \mathrm{SO}_{4}$ và $\mathrm{KNO}_{3}$. Tuy nhiên, tùy mỗi chủng vi khuẩn Streptomyces sp. khác nhau được phân lập và sử dụng thì nhu cầu phù hợp về thành phần dinh dưỡng có thể sẽ khác nhau. Nhìn chung, bổ sung vào môi trường nuôi nguồn dinh dưỡng nitrogen hữu cơ cho thấy hiệu quả hơn nguồn vô cơ vì sự đa dạng của các amino acid.

\section{5. Ảnh hưởng thời gian nuôi cấy đến hoạt tính enzyme protease}

Hình 6 cho thấy hoạt tính enzyme protease có xu hướng tăng dần theo thời gian, đạt giá hoạt tính cao sau 96 giờ nuôi, đặc biệt sau 144 giờ $(42,7 \pm 1,9$ $\mathrm{U} / \mathrm{mg}$ ) và khác biệt có ý nghĩa so với các mốc thời gian còn lại $(\mathrm{p}<0,05)$. Trong khi đó, hoạt tính thấp nhất ghi nhận được sau 24 giờ nuôi $(12,4 \pm 4 \mathrm{U} / \mathrm{mg})$. Trái ngược với kết quả nghiên cứu của Akhtar et al. (2013), Streptomyces albolongus và Streptomyces aburaviensis sinh hoạt tính protease cao nhất sau 120 giờ nuôi và có xu hướng giảm dần theo thời gian.

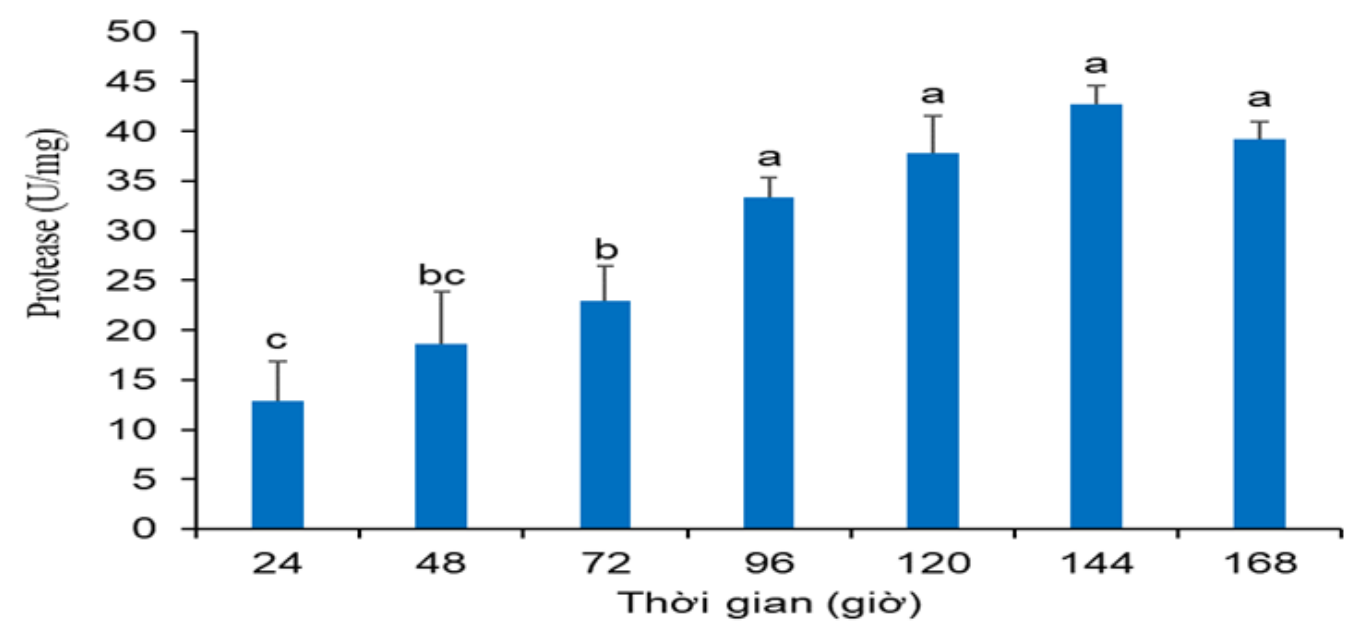

Hình 6. Ảnh hưởng của thời gian lên hoạt tính enzyme protease

Các ký tự khác nhau trên mỗi cột cho thấy sự khác biệt giũa các mốc thời gian trong thí nghiệm $(p<0,05)$. 
Protease thu nhận từ chủng Streptomyces DH3.4 là enzyme protase ngoại bào được vi khuẩn tổng hợp và tiết ra trong quá trình sinh trưởng. Mỗi thời điểm trong chu kỳ sinh trưởng vi khuẩn sẽ sinh tổng hợp enzyme với nồng độ và hoạt độ khác nhau. Nểu thu nhận enzyme quá sớm, nồng độ và hoạt tính enzyme protease sẽ thấp. Ngược lại, nếu kéo dài thời điểm thu nhận enzyme thì lượng enzyme tiết ra môi trường quá nhiều sẽ ảnh hưởng lẫn nhau và enzyme chịu tác động của các yếu tố môi trường bên ngoài sẽ làm giảm hoạt tính enzyme hay phá hủy cấu trúc tự nhiên của enzyme. Có thể ứng dụng kêt quả của nghiên cứu này để phát triển tiềm năng probiotic vì các enzyme ngoại bào đóng vai trò quan trọng trong việc hỗ trợ tiêu hóa thức ăn, giúp thức ăn dễ hấp thu, và vật nuôi tăng trọng tốt. Do đó, khả năng sinh enzyme ngoại bào là một tiêu chí quan trọng khi chọn lọc các chủng vi khuẩn làm probiotic. Theo nghiên cứu Lê Thị Hải Yến và Nguyễn Đức Hiền (2016), các loài $B$. subtilis AG27, AG60, VL05 và VL28 đều có các đặc tính để làm nguồn nguyên liệu sản xuất probiotic.

\section{KẾT LUẬN}

Hoạt tính enzyme protease thu nhận từ chủng Streptomyces DH3.4 cao nhất khi nuôi cấy in vitro trong môi trường $\mathrm{SCB}$ ở $\mathrm{pH} 7,0$ và $1,5 \% \mathrm{NaCl}$ trong 144 giờ nuôi cấy. Nguồn carbon để thu hoạt tính protease cao nhất là tinh bột, trong khi đó malt extract và $\left(\mathrm{NH}_{4}\right)_{2} \mathrm{SO}_{4}$ là nguồn đạm hữu cơ và vô cơ tốt nhất. Tuy nhiên, những nghiền cứu về khả năng sản xuất và bảo quản enzyme protease ở quy mô lớn hơn cần phải được đánh giá trong các nghiên cứu tiếp theo.

\section{LỜI CẢM TẠ}

Đề tài này được tài trợ bởi Dự án Nâng cấp Trường Đại học Cần Thơ VN14-P6 bằng nguồn vốn vay ODA từ Chính phủ Nhật Bản.

\section{TÀI LIỆU THAM KHẢO}

Akhtar, N., Mahmud, A.S.M., Khan, M.S., Taznin, T., Haque, M.E., Sultana S. \& Sultana, S. (2013). Effects of cultural conditions on the production of extracellular protease by Streptomyces albolongus and Streptomyces aburaviensis. Enzyme Engineering, 2(2), 1-5.

APHA. (2017). Standard Methods for the Examination of Water and Wastewater ( $23^{\text {rd }}$ ed.), American Public Health Association, American Water Works Association, Water Environment Federation, Denver.

Al-Dhabi, N. A., Esmail, G. A., Ghilan, A. K. M., Arasu, M. V., Duraipandiyan, V., \&
Ponmurugan, K. (2020a). Characterization and fermentation optimization of novel thermo stable alkaline protease from Streptomyces sp. AlDhabi-82 from the Saudi Arabian environment for eco-friendly and industrial applications. Journal of King Saud UniversityScience, 32(1), 1258-1264.

Al-Dhabi, N. A., Esmail, G. A., Ghilan, A. K. M., \& Arasu, M. V. (2020b). Isolation and screening of Streptomyces sp. Al-Dhabi-49 from the environment of Saudi Arabia with concomitant production of lipase and protease in submerged fermentation. Saudi journal of biological sciences, 27(1), 474-479.

Đỗ Thị Bích Thủy. (2012). Nghiên cứu các yếu tố ảnh hưởng đến sự thu nhận chế phẩm protease ngoại bào của Bacillus amyloliquefacien N1. Tap chi khoa học trường Đại học Huế, 71(2), 279-290.

Fernandes, S., Kerkar, S., Leitao, J. \& Mishra, A. (2019). Probiotic role of salt pan Bacteria in enhancing the growth of whiteleg shrimp, Litopenaeus vannamei. Probiotics and antimicrobial proteins, 11(4), 1309-1323.

Haritha, R., SivaKumar, K., Swathi, A., Jagan Mohan, Y.S.Y.V. \& Ramana, T. (2012). Characterization of Marine Streptomyces carpaticus and optimization of conditions for production of extracellular protease. Microbiology Journal, 2(1), 23-35.

Huynh, T.G., Nguyen, T.P., Tran, T.T.H., Chi, C.C., Cheng, A.A. \& Liu, C.H. (2018). Effects of synbiotic containing Lactobacillus plantarum 7-40 and galacto-oligosaccharide on the growth performance of white shrimp, Litopenaeus vannamei. Aquaculture Research. 46, 2416-2428.

Jayasree, D., T.D.S. Kumari, P.B.K. Kishor, M.V. Lakshmi \& M.L. Narasu. (2009). Optimization of production protocol of alkaline protease by Streptomyces pulvereceus. Int. JRI Sci. and Technology, 1(2), 79-82.

Lê Thị Hải Yến và Nguyễn Đức Hiền. (2016). Khảo sát đặc tính probiotic các chủng vi khuẩn Bacillus subtilis phân lập tại các tỉnh đồng bằng sông Cửu Long. Tạp chí Khoa hoc Truòng Đại hoc Cần Tho, Số chuyên đề: Nông nghiệp(Tập 2), 26-32.

Lowry, O.H., Rosebrough, N.J., Farr, A.L., \& Randall, R.J. (1951). Protein measurement with the folin phenol reagent. Journal of Biological Chemistry, 193(1), 265-275.

Nayera A.M. Abdelwahed, Enas N. Danial, Noura El-Ahmady El-Naggar \& Asem A. Mohamed. (2014). Optimization of alkaline protease production by Sstreptomyces ambofaciens in free and immobilized form. American Journal of Biochemistry and Biotechnology, 10(1), 1-13. 
Nomoto Masao, Narahashi Yoshiko \& Murakami Mitsuru. (1960). A proteolytic enzyme of Streptomyces griseus. Hydrolysis of protein by Streptomyces griseus protease. The Journal of Biochemistry, 48(4), 593-602.

Phạm Văn Nhuần, 2020. Phân lập và tuyển chọn một số dòng xạ khuẩn ứng dụng trong nuôi trồng thủy sản. Luận văn thạc sĩ, Trường Đại học Cần Thơ.

Sengupta, S., \& Paul, A. K. (1992). Nutritional conditions for the germination of streptomyces galbus 5ME-13 spores. Acta Biotechnologica, 12(3), 223-228.
Shatoury, S. A., Ameen, F., Moussa, H., Abdul Wahid, O., Dewedar, A. \& Al Nadhari, S. (2020). Biocontrol of chocolate spot disease (Botrytis cinerea) in faba bean using endophytic actinomycetes Streptomyces: a field study to compare application techniques. Peerj-Life \& Environtment, 8(3), 2-14.

van Veen, J.A., \& Paul, E.A. (1979). Conversion of biovolume measurements of soil organisms, grown under various moisture tensions, to biomass and their nutrient content. Applied and Environmental Microbiology, 37(4), 686-692. 